\title{
Synthesis of new, optically active 1-(substituted aryl)pyrrole derivatives via atropisomerism directed diastereoselective metalation
}

\author{
Angelika Thurnera ${ }^{a}$, Bernadett Vas-Feldhoffer ${ }^{b}$, Éva Bottka $^{b}$, Tamás Holczbauer ${ }^{c}$, \\ Miklós Nyerges, ${ }^{\text {d }}$ and Ferenc Faigl ${ }^{a, b_{*}}$ \\ ${ }^{a}$ MTA-BME Organic Chemical Technology Research Group, Hungarian Academy of Sciences, \\ H-1111 Budapest, Budafoki út 8., Hungary \\ ${ }^{b}$ Department of Organic Chemistry and Technology, Budapest University of Technology and \\ Economics, H-1111 Budapest, Budafoki út 8., Hungary \\ ${ }^{c}$ Institute of Structural Chemistry, Hungarian Academy of Sciences, 1117 Budapest, Magyar \\ tudósok körútja 2., Hungary \\ ${ }^{d}$ Servier Research Institute of Medicinal Chemistry, H-1031 Budapest, Záhony u. 7., Hungary \\ E-mail: ffaigl@mail.bme.hu
}

\section{Dedicated to Prof. Manfred Schlosser in honor of his scientific achievements}

DOI: $\underline{\text { http://dx.doi.org/10.3998/ark.5550190.p009.023 }}$

\begin{abstract}
Axial chirality directed highly diastereoselective formation of a new stereogenic center in the benzylic position of racemic and optically active 1-[2-(carboxymethyl)-6-ethylphenyl]-1Hpyrrole-2-carboxylic acid (4) is reported as the very first example of efficient intramolecular asymmetric induction effect of the atropisomeric 1-phenylpyrrole skeleton containing dicarboxylic acid on the metalation, alkylation reaction sequence. Configuration of a product $\left(\left(R_{a}, S\right)-7 \mathbf{a}\right)$ was determined by single crystal X-ray diffraction measurements. In addition, stereochemical stability of the new, two chirality elements containing compounds was demonstrated by selective, stepwise transformation of the carboxylic groups into ester and amide functions, respectively.
\end{abstract}

Keywords: Atropisomer, diastereoselective metalation, asymmetric induction, chiral 1phenylpyrroles, stereoselective alkylation 


\section{Introduction}

Generation of new chirality elements (central or axial) using chiral catalysts or chiral auxiliaries is the basis for asymmetric synthesis of enantiomerically enriched chiral molecules. The efficiency of the asymmetric induction or chirality transfer is largely dependent on how tight the interaction is between the chirality source and the reacting site. ${ }^{1}$ Numerous examples have been published for intermolecular asymmetric inductions where a chiral catalyst determines the configuration of the formed new stereogenic center(s) in the product. Atropisomers, resulting from highly sterically hindered rotation of one single bond have received great interest from chemists due to their widespread appearance in artificial chiral ligands for asymmetric catalysis. $^{2-5}$ There are also examples in the literature for such type of chirality transfer, when the axial chirality of the starting material is used to build up a new stereogenic center of the cyclization product. ${ }^{6}$ Efficient creation of new stereogenic centers has been accomplished by Clayden and his co-workers in diastereoselective reactions starting from bulky $N$-substituents containing benzamides and naphthamides. ${ }^{7-8}$ Directed lateral lithiation of $N, N$-diisopropyl-2ethyl-naphtalene-1-carboxamide followed by ethyl iodide quench yielded the $\alpha$-ethyl derivative with a high degree of diastereoselectivity (98/2=syn/anti) due to the CIPE effect and the quasi atropisomeric character of the naphtamide moiety. ${ }^{9}$ Simpkins et al. also achieved high diastereoselectivity in alkylation and aldol reactions of an atropisomeric anilide in which the nitrogen contained propanoyl and methoxyethoxymethyl groups and the rotation of the amido moiety was controlled by the steric hindrance of an ortho tert-butyl group. ${ }^{10}$

In the last decade Clayden published numerous articles on the behaviour and diastereoselective reactions of benzamide derivatives having atropisomeric character. ${ }^{11-14}$ Efficient intramolecular control of enantioselectivity by atropisomeric remote amide conformation has also been studied in $\mathrm{SmI}_{2}$-mediated reductive coupling of aldehydes with the crotonates possessing different 2-substituted 8-methoxy-1-naphthamides. ${ }^{15}$ Recent developments in the field of intramolecular remote control of stereogenic center(s) formation using asymmetric center or atropisomeric benzamide containing compounds have also been reviewed. ${ }^{16}$

Recently a new class of atropisomeric biaryls, namely the family of 1-phenylpyrrole skeleton containing chiral compounds has been developed in our laboratory. ${ }^{17-20}$ The very first member $\left(\left(S_{a}\right)\right.$-1) (Scheme 1) of this group was prepared from 1-(2-trifluoromethylphenyl)-1H-pyrrole via selective dimetalation carboxylation reaction sequence. Racemic dicarboxylic acid was resolved into the two stable atropisomers ${ }^{17,21}$ and the pure enantiomers were used as starting materials of the synthesis of optically active ligands $\left(\left(S_{a}\right)-2\right)($ Scheme 1$) .^{22}$ 
<smiles>O=C(O)c1cccc(C(=O)O)c1-n1cccc1C(F)(F)F</smiles>

$\left(S_{a}\right)-1$<smiles>[R]NCc1cccn1-c1c(CO)cccc1C(F)(F)F</smiles>

$\left(S_{a}\right)-2\left(R^{1}, R^{2}=H\right.$, alkyl)

Scheme 1. Optically active 1-phenylpyrrole derivatives.

Dimetalation and consecutive carboxylation of 1-(2-ethyl-6-methylphenyl)-1H-pyrrole (3) has also provided an atropisomeric dicarboxylic acid ( $r a c-4)$ which was separated into its two enantiomers via diastereoisomeric salt formation using optically active 1-methylbenzylamine $((R)-5$, Scheme 2$) .{ }^{20}$ Optically active $\mathbf{4}$ contains a prochiral benzylic group and enantioselective introduction of a substituent into this position could provide us a new chiral building block with both axial and central chirality elements. However, according to our best knowledge, nobody has studied remote lateral metalation of atropisomeric 1-phenylpyrrole derivatives until now. Therefore we aimed to investigate the asymmetric induction of axial chirality of $\mathbf{4}$ on the formation of the new stereogenic center in benzylic position and the enantioconservative transformation of the formed product into ester and amide derivatives.

\section{Results and Discussion}

Synthesis and optical resolution of the starting material (4) was accomplished according to the literature procedure ${ }^{20}$ (Scheme 2).

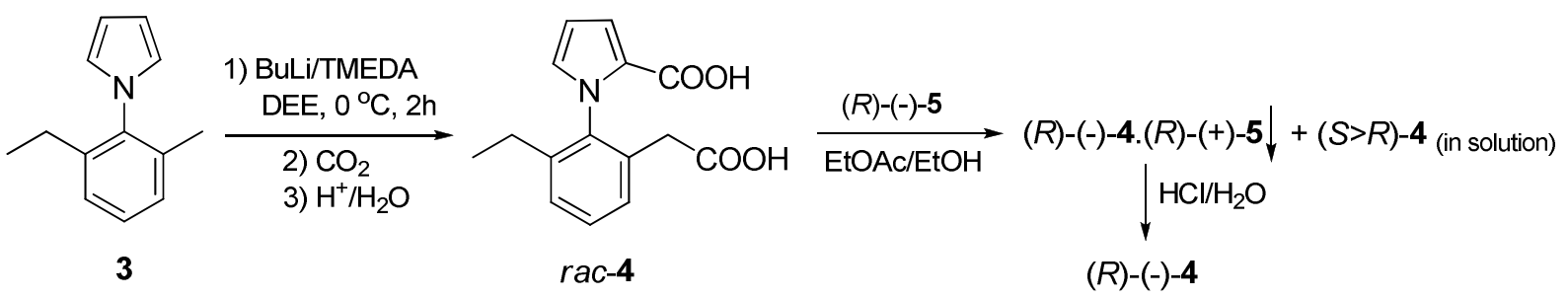

Scheme 2. Synthesis and resolution of rac-4.

Then metalation alkylation reaction sequence was studied starting from rac-4. The dicarboxylic acid was reacted with three equivalents of potassium tert-butoxide activated lithium diisopropylamide (LiDA-KOR) superbase in tetrahydrofuran at $-75{ }^{\circ} \mathrm{C}$ (Scheme 3). Clean benzylic metalation occurred under these conditions and the organometallic intermediate (6) readily reacted with different electrophiles (iodomethane, isobutyl bromide, benzyl bromide and benzaldehyde). The products (7a-d) were isolated, after recrystallization, with good to 
satisfactory yields (Table 1). It has to mention, that only starting material was recovered when dimethylformamide or benzophenone was added to compound $\mathbf{6}$.

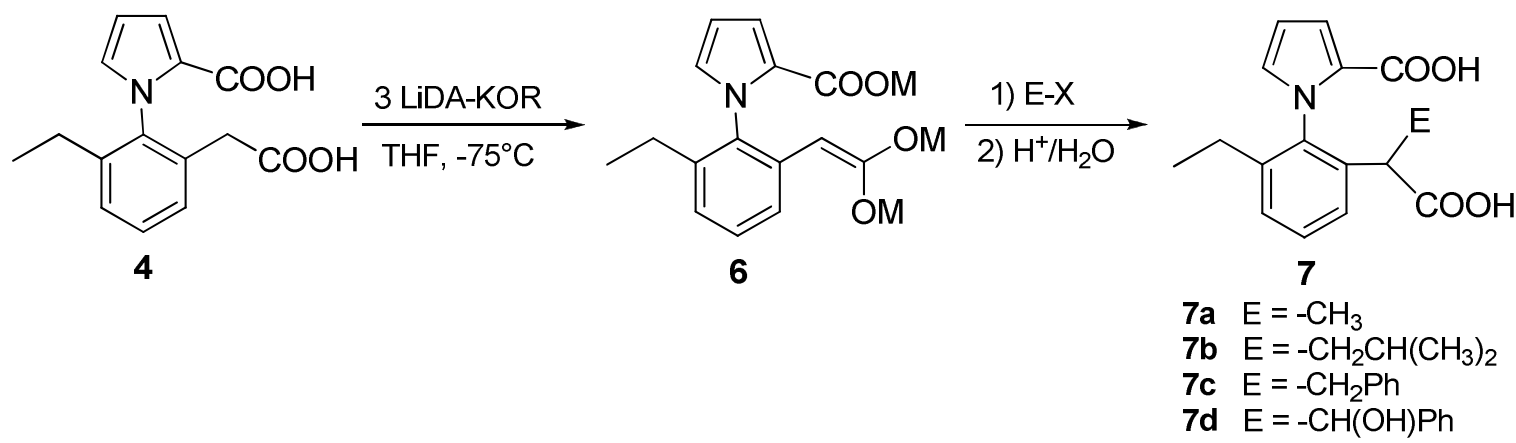

Scheme 3. Preparation of compounds 7a-d $(\mathrm{M}=\mathrm{K}$ (or Li)).

Beside the axial chirality, compounds 7a-d contain a new asymmetric carbon atom in benzylic position, therefore two diastereoisomeric pairs should be formed from the racemic starting material (rac-4). However, according to the ${ }^{1} \mathrm{H}-\mathrm{NMR}$ spectra of compounds 7a-d, only one diastereoisomer was formed in each case. Consequently, the axial chirality of the starting material (rac-4) completely determined the stereochemical outcome of the metalation/alkylation reaction sequence.

Table 1. Results of the consecutive metalation and alkylation of rac-4

\begin{tabular}{cccccc}
\hline \multirow{2}{*}{ Entry } & \multirow{2}{*}{ Reagent } & \multirow{2}{*}{ Product } & \multicolumn{2}{c}{ Crude product } & Recrystallized product $^{\mathrm{b}}$ \\
\cline { 3 - 5 } & & $\mathbf{7 : 4}$ ratio $^{\text {a }}$ & Yield & Yield $^{\mathrm{c}}$ \\
\hline 1 & iodomethane & $\mathbf{7 a}$ & $100: 0$ & $84 \%$ & $80 \%$ \\
2 & isobutyl bromide & $\mathbf{7 b}$ & $87: 13$ & $79 \%$ & $50 \%$ \\
3 & benzyl bromide & $\mathbf{7 c}$ & $87: 13$ & $77 \%$ & $53 \%$ \\
4 & benzaldehyde & $\mathbf{7 d}$ & $81: 19$ & $80 \%$ & $74 \%$ \\
\hline
\end{tabular}

${ }^{a}$ Product distribution was determined from the ${ }^{1} \mathrm{H}-\mathrm{NMR}$ spectra of the crude product. ${ }^{\mathrm{b}}$ The crude product was purified by recrystallization from ethyl acetate. ${ }^{\mathrm{c}}$ Calculated to the amount of the starting material 4.

In order to prove this supposition, the methylation reaction was repeated with $\left(R_{a}\right)-(-)-4$ as starting material. A single enantiomer was isolated as the only product $((+)-7 \mathbf{a})$ and it was suitable to preparation of single crystals (grown from ethanol/diethyl ether mixture). Hence, $\mathrm{X}$ ray diffraction measurements were carried out to determine the absolute configuration of the new asymmetric carbon atom in (+)-7a (Figure 1). 


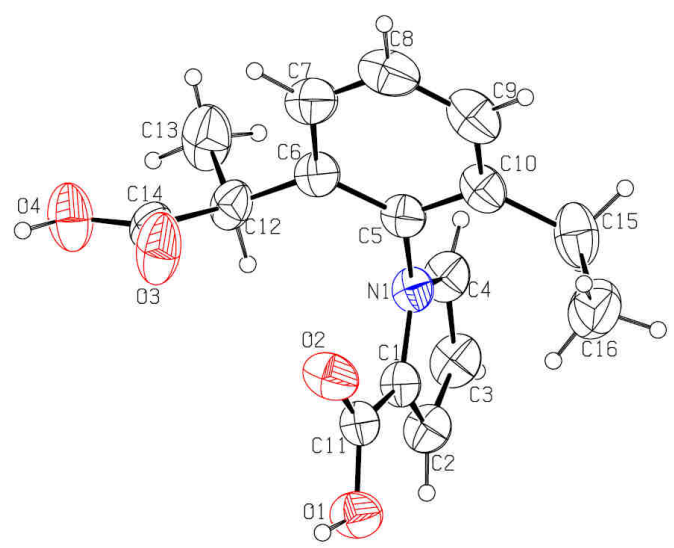

Figure 1. Final crystal structure of $\left(R_{a}, S\right)-(+)-7 \mathbf{a}$ with $30 \%$ probability anisotropic displacement ellipsoids for non-H atoms. ${ }^{23}$

In previous studies ${ }^{20}$ we have determined the absolute configuration of $\left(R_{a}\right)-(-)-4$. This axial chirality did not change during the introduction of the methyl group into the benzylic position. It is also evident from the determined molecular structure, that the absolute configuration of the new asymmetric carbon atom (C12 in Figure 1) is $S$. This high stereoselectivity can be rationalised if one take into account that methyl group could only join to the benzylic carbon atom from the Si face of the organometallic intermediate $\mathbf{6}$, because the other side of the reaction center was shadowed by the alkali carboxylate moiety connected to the $\alpha$-position of the pyrrole ring like the proposed model structure $\mathbf{8}$ (Scheme 4).<smiles>CCc1cccc(CC(=O)O)c1-n1cccc1C(=O)O</smiles>

Scheme 4. Synthesis of $\left(R_{a}, S\right)-(+)-7 \mathbf{a}$ (possible diisopropyl amine and THF ligands of the metal cations $\left(\mathrm{M}^{+}\right)$are not depicted in $\mathbf{8}$ for clarity).

We suppose that structure of $\mathbf{8}$ is stabilized by the Coulomb interactions among the two alkali cations and the negatively charged oxygen atoms of the two carboxylate groups, respectively. This way the axial chirality of $\mathbf{4}$ strictly determines the configuration of the new asymmetric center.

Optically active $\left(R_{a}, S\right)-(+)-7 \mathbf{a}$ can serve as a useful intermediate of new chiral ligands and organocatalyst, therefore selective, stepwise transformations of the two carboxylic groups were also investigated. Highly selective monoesterification of (S)-1-[2-carboxy-6- 
(trifluoromethyl)phenyl]-pyrrole-2-carboxylic acid ((S)-1) has been published by our laboratory. ${ }^{22}$ After stirring the dicarboxylic acid $(S)$-1 for 48 hours at room temperature in methanol, in the presence of 7 equivalents thionyl chloride, the carboxylic group connected to the phenyl ring was selectively esterified. In that case the effects of the electron withdrawing trifluoromethyl group of the benzene ring and the electron donating effect of the pyrrole ring toward the carbonyl group caused significant difference between the reactivities of the two carboxylic groups of $(S)-\mathbf{1}$. As a consequence, the monoester could be prepared selectively even a large excess of thionyl chloride was used in methanolic solution for esterification. ${ }^{22}$

The situation is different in the case of $\left(R_{a}, S\right)-(+)-7 \mathbf{a}$ because electron donating alkyl groups are connected to the benzene ring and the benzylic carbon atom, respectively, which decrease the reactivity of the connected carboxylic group in such esterification reaction. In order to test the residual reactivity difference between the two carboxylic functions in (-)-4 and (+)-7a, both optically active compounds were treated with an excess of thionyl chloride in dry ethanol. In principle, during the esterification process three products may be formed: two monoesters ( 9 and 10) and the diester (11) (Scheme 5).

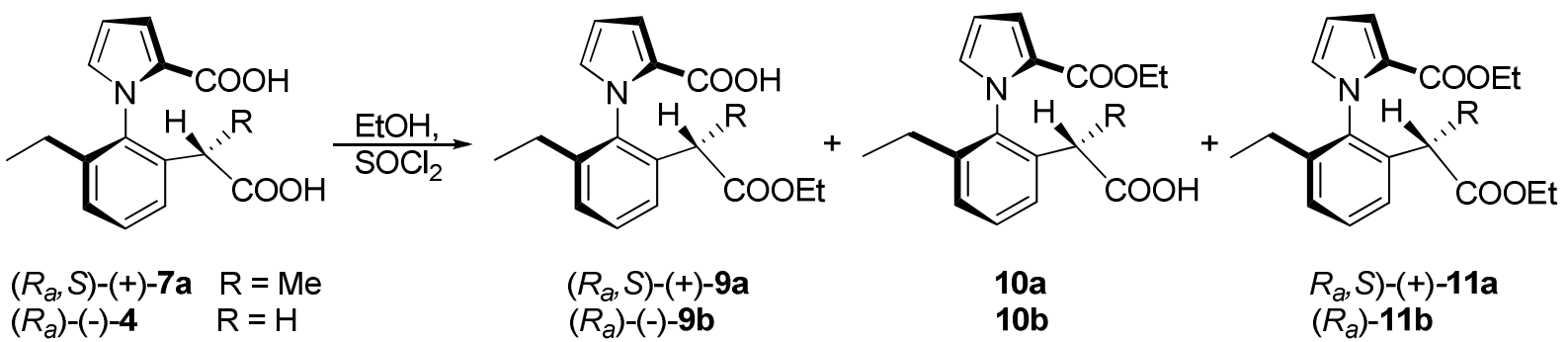

Scheme 5. Esterification of $\left(R_{a}\right)-(-)-4$ and $\left(R_{a}, S\right)-(+)-7 \mathbf{a}$, and the possible products.

When $\left(R_{a}\right)-(-)-4$ dicarboxylic acid was esterified in presence of two equivalents of thionyl chloride with ethanol for 22 hours at room temperature, mainly the monoester $\left(\left(R_{a}\right)-(-)-9 \mathbf{b}\right)$ was formed together with a small amount of diester 11b. This selectivity decreased considerably when $\left(R_{a}, S\right)-(+)-7 \mathbf{a}$ was used as starting material because, according to the chromatographic and ${ }^{1} \mathrm{H}-\mathrm{NMR}$ investigations, the crude product mixture contained considerably more the diester $\left(\left(R_{a}, S\right)-(+)-11 \mathrm{a}\right)$ together with the major product $\left(R_{a}, S\right)-(+)-9 \mathrm{a}$. Decreasing of regioselectivity in case of $\left(R_{a}, S\right)-(+)-7 \mathbf{a}$ may be explained by the above mentioned electronic effect of the methyl group.

On the basis of these experimental findings, two methods have been developed for producing pure $\left(R_{a}, S\right)-(+)-9 \mathrm{a}$ : selective hydrolysis of $\left(R_{a}, S\right)-(+)-11 \mathrm{a}$ diester, and selective time-controlled monoesterification of $\left(R_{a}, S\right)-(+)-7 \mathbf{a}$ (Scheme 6).

The diester derivative $\left(\left(R_{a}, S\right)-(+)-\mathbf{1 1 a}\right)$ formed easily by stirring $\left(R_{a}, S\right)-(+)-\mathbf{7 a}$ dicarboxylic acid in ethanol solution with 7 equivalents amount of thionyl chloride, at room temperature. Subsequently, the resultant diester $\left(\left(R_{a}, S\right)-(+)-11 a\right)$ was treated at room temperature with exactly 1 equivalent amount sodium hydroxide containing water/ethanol $=1 / 99$ solution. After the 
working-up procedure pure $\left(R_{a}, S\right)-(+)-9$ a monoester was obtained without any loss of the enantiomeric purity.

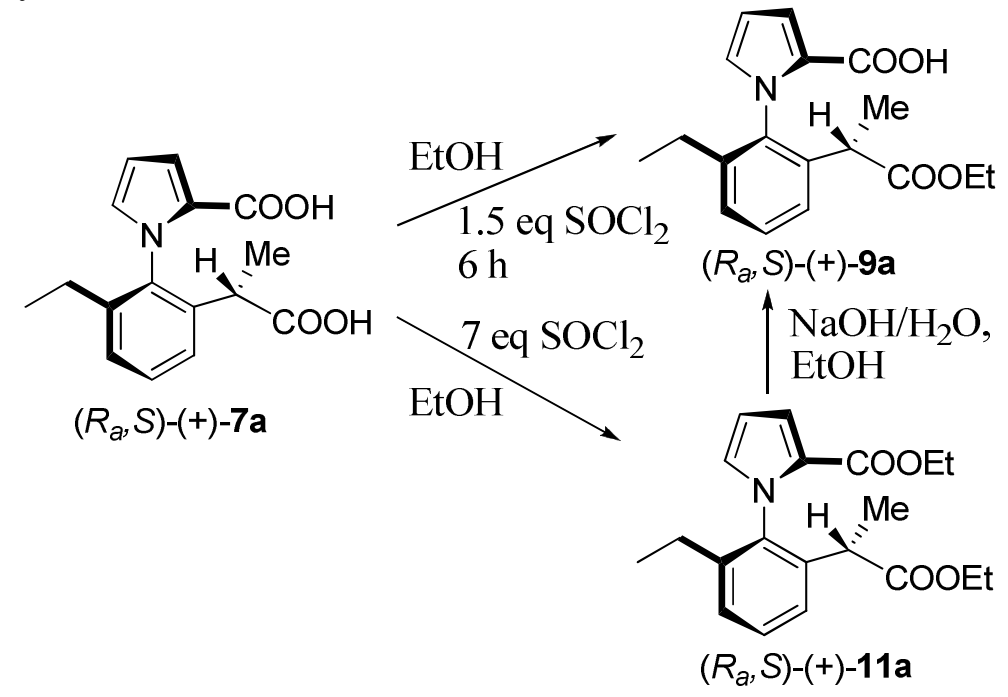

Scheme 6. Two highly selective methods for preparation of optically active $\left(R_{a}, S\right)-(+)-9 \mathbf{a}$ monoester.

A simpler, but far more sensitive method for preparation of $\left(R_{a}, S\right)-(+)-9 \mathbf{a}$ monoester is the direct esterification of $\left(R_{a}, S\right)-(+)-7 \mathbf{a}$ by using 1.5 equivalents of thionyl chloride in ethanol. To avoid diesterification, the progress of the esterification reaction should be monitored by TLC or other suitable methods. According to the ${ }^{1} \mathrm{H}-\mathrm{NMR}$ and ${ }^{13} \mathrm{C}-\mathrm{NMR}$ spectra of the products obtained after the selective hydrolysis and the selective monoesterification, respectively, $\left(R_{a}, S\right)$ (+)-9a monoester formed in both cases. These experimental results may be rationalised if one take into consideration that esterification is governed by the acidity difference of the two carboxylic groups while basic hydrolysis occurs more easily on the sterically less hindered site of the molecule.

In order to determine the exact structure of $\left(R_{a}, S\right)-(+)-9 \mathrm{a}$, two dimensional ${ }^{1} \mathrm{H},{ }^{13} \mathrm{C}-\mathrm{HMBC}$ spectroscopic measurements were performed. These measurements confirmed without doubt that the ethoxycarbonyl group is connected to the carbon atom of the benzylic $-\mathrm{CH}\left(\mathrm{CH}_{3}\right)$ - group.

The free carboxylic groups of the optically active half esters $\left(R_{a}, S\right)-(+)-9 \mathbf{a}$ and $\left(R_{a}\right)-(-)-9 \mathbf{b}$ were converted into the corresponding optically active $N, N$-diethylamide $\left(\left(R_{a}, S\right)-(+)-\mathbf{1 2 a}\right.$ and $\left(R_{a}\right)-(-)-$ 12b) derivatives (Scheme 7). 


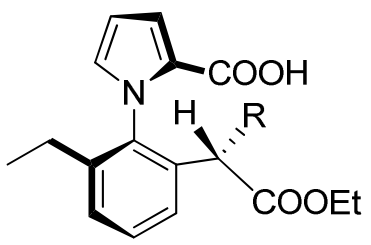

$\left(R_{a}, S\right)-(+)-9 a \quad \mathrm{R}=\mathrm{Me}$ $\left(R_{a}\right)-(-)-9 b \quad \mathrm{R}=\mathrm{H}$
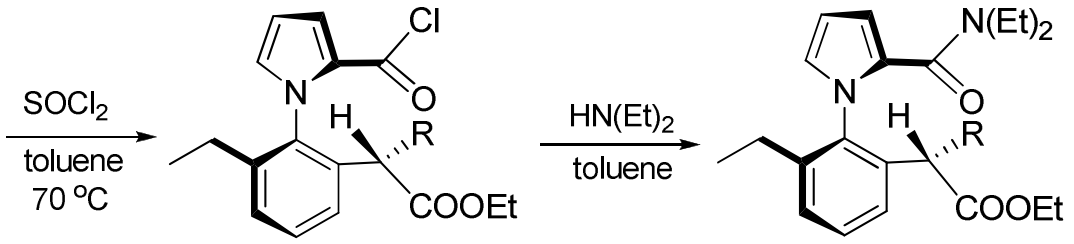

$\left(R_{a}, S\right)-(+)-12 a$

$\left(R_{a}\right)-(-)-12 b$

Scheme 7. Preparation of optically active amides $\mathbf{1 2 a}$ and $\mathbf{1 2 b}$.

The carboxylic groups of $\left(R_{a}, S\right)-(+)-9 \mathbf{a}$ and $\left(R_{a}\right)-(-)-9 \mathbf{b}$ were transformed into the corresponding acid chlorides in toluene at $70{ }^{\circ} \mathrm{C}$ before the addition of $N, N$-diethylamine and, in spite of the applied high temperature, the products were isolated without any loss of their enantiomeric purities. The above mentioned experimental data (half ester and amide formation reactions) confirmed that the prepared new optically active compounds are stereochemically stable, they axial and the central chirality remained intact under the applied conditions.

\section{Conclusions}

Experimental results of the metalation alkylation reaction sequence of racemic and optically active 1-[2-(carboxymethyl)-6-ethylphenyl]-1H-pyrrole-2-carboxylic acid (4) let us to conclude that the chiral information of the atropisomeric 1-phenylpyrrole skeleton containing dicarboxylic acid can be completely transmitted to the intramolecular benzylic position. Diastereoselectivity of the metalation could be explained by the complex formation of the pyrrole connected carboxylate anion with the metal ion of the metalated carboxymethyl moiety of the molecule as shown in structure 8. Steric arrangement of this complex is strictly determined by the axial chiraltity of the molecule, thus only one side is free for the reaction with the electrophilic reagents. Single crystal X-ray diffraction measurements have confirmed the above mentioned model structure and provided us the absolute configuration of the new asymmetric carbon atom. According to reactivity difference between the two carboxylic groups, two methods have also been developed for selective monoestericication of dicarboxylic acids $\left(R_{a}\right)-(-)-4$ and $\left(R_{a}, S\right)-(+)-$ 7a. The monoesters were transformed into the optically active half ester-half amide derivatives $\left(\left(R_{a}, S\right)-(+)-12 \mathrm{a}\right.$ and $\left.\left(R_{a}\right)-(-)-12 \mathbf{b}\right)$. These reactions confirmed the supposed stereochemical stabilities of the investigated compounds. Consequently, the synthetized new optically active 1phenylpyrrole derivatives may be used as building blocks of new chiral ligands and organocatalysts. 


\section{Experimental Section}

General. All commercial starting materials were purchased from Sigma-Aldrich Hungary and Merck Hungary Kft. and were used without further purification. Tetrahydrofuran was obtained anhydrous by distillation from sodium wire, after the characteristic blue colour of the in situ generated sodium diphenylketyl had been found to persist. The organometallic reactions were carried out in Schlenk flasks under a dry nitrogen atmosphere. Thin-layer chromatography (TLC) was carried out on Kieselgel $60 \mathrm{~F}_{254}$ (Merck) sheets (visualization of the products was made by exposing the plate to UV radiation or by staining it with the aqueous solution of $\left(\mathrm{NH}_{4}\right)_{6} \mathrm{Mo}_{7} \mathrm{O}_{24}$, $\mathrm{Ce}\left(\mathrm{SO}_{4}\right)_{2}$, and sulphuric acid. Routine ${ }^{1} \mathrm{H}$ NMR and ${ }^{13} \mathrm{C}$ NMR spectra were recorded in $\mathrm{CDCl}_{3}$ solution or in DMSO- $\mathrm{d}_{6}$ on BRUKER AV 300 and DRX 500 spectrometers. Proton chemical shifts are reported in ppm relative to the internal standard tetramethylsilane $\left(\delta_{\mathrm{TMS}}=0 \mathrm{ppm}\right)$ or solvents $\left(\delta_{\text {DMSO }}=2.50 \mathrm{ppm}\right)$, and carbon chemical shifts are reported in ppm relative to the solvents $\left(\delta_{\mathrm{CDCl} 3}=77.00, \delta_{\mathrm{DMSO}}=39.7\right)$.

Specific rotation power of the optically active samples was determined on a Perkin-Elmer 245 MC polarimeter using a sodium lamp $(589 \mathrm{~nm})$. Melting points were determined on a Gallenkamp Melting Point Apparatus (in capillaries). High-resolution mass spectra (HRMS) were recorded on Waters LCT Premier XE spectrometer in electrospray ionization (ESI, $2.5 \mathrm{kV}$ ) mode, using water $(0.035 \%$ trifluoroacetic acid)/acetonitrile $(0.035 \%$ trifluoroacetic acid $)$ as eluent in gradient elution (5\%-95\% acetonitrile); samples were made up in acetonitrile.

\section{1-[2-(Carboxymethyl)-6-ethylphenyl]-1H-pyrrole-2-carboxylic acid (rac-4). ${ }^{20}$ Compound} rac-4 was prepared by condensation of 2-ethyl-6-methylaniline and cis,transdimethoxytetrahydrofuran in glacial acid $^{4}$ followed by consecutive dimetalation and carboxylation of 1-(2-ethyl-6-methylphenyl)pyrrole according to the literature procedure. ${ }^{20}$

Rac-4: colourless crystals from chloroform, yield 79\%, mp 212-213 ${ }^{\circ} \mathrm{C}$; IR $\left(v_{\max }, \mathrm{cm}^{-1}\right): 1667$ and $1716(\mathrm{C}=\mathrm{O}), 3448(\mathrm{OH}) .{ }^{1} \mathrm{H}-\mathrm{NMR}\left(500 \mathrm{MHz}, \mathrm{DMSO}-d_{6}\right): \delta_{\mathrm{H}} 0.97\left(3 \mathrm{H}, \mathrm{t}, J 7.6, \mathrm{C}_{3}-\mathrm{CH}_{2}\right)$, $2.10\left(2 \mathrm{H}, \mathrm{q}, J\right.$ 7.6, $\left.\mathrm{CH}_{3}-\underline{\mathrm{C}}_{2}\right), 2.98(1 \mathrm{H}, \mathrm{d}, J 16.2,-\mathrm{CHH}), 3.28(1 \mathrm{H}, \mathrm{d}, J 16.2,-\mathrm{CH} \underline{\mathrm{H}}), 6.31(1 \mathrm{H}, \mathrm{t}$ like $\mathrm{m}, J 2.7, \mathrm{H}_{\beta}$, $6.80\left(1 \mathrm{H}, \mathrm{t}\right.$ like $\left.\mathrm{m}, J 1.7, \mathrm{H}_{\beta}\right), 7.00\left(1 \mathrm{H}, \mathrm{q}\right.$ like $\left.\mathrm{m}, J 1.5, \mathrm{H}_{\alpha}{ }^{\prime}\right), 7.30(3 \mathrm{H}, \mathrm{m}, \mathrm{Ph})$, $12.07\left(2 \mathrm{H}\right.$, br s, OH); ${ }^{13} \mathrm{C}-\mathrm{NMR}\left(75 \mathrm{MHz}, \mathrm{DMSO}-d_{6}\right): \delta_{\mathrm{C}} 172.1,160.8,141.1,138.7,132.9$, $129.8,128.2,128.1,127.2,124.2,117.5,109.2,36.4,23.5,14.9$; UV/VIS (EtOH, $\lambda[n m], \varepsilon\left[\mathrm{M}^{-}\right.$ ${ }^{1} \mathrm{~cm}^{-1}$ ]): 262, 25300; 215 (sh), 28700.

Resolution of rac-4. ${ }^{20}$ The racemic dicarboxylic acid (rac-4) was resolved according to the literature procedure ${ }^{20}$ in a mixture of ethyl acetate and dry ethanol $(0.25 \%)$ with half equivalent amount of $(R)$-1-methylbenzylamine $((R)-5)$. From the crystalline salt $\left(R_{a}\right)-(-)-4$ was isolated, yield: $108 \%$ (calculated to the (-)-enantiomer content of rac-4). $[\alpha]_{D}^{25}=-71.4$ (c: 1.14 , ethanol), $e e=83.5 \%$; From the filtrate the other isomer $\left(S_{a}\right)-(+)-4$ was isolated, yield $88 \%$ (calculated to the (+)-enantiomer content of rac-4). $[\alpha]_{D}^{25}=+64.3$ (c: 1.08 , ethanol), ee $=75.2 \%$. For enantiomeric enrichment the resolution process was repeated. Repeated resolution was carried 
out analogously, but the amount of the resolving agent was equivalent with the corresponding enantiomer content of the starting optically active 4 . The $\left(S_{a}\right)-(+)-\mathbf{4}$ isomer was treated with $(S)-5$ and $\left(R_{a}\right)-(-)-4$ was resolved again with $(R)-5$.

Enantiomeric enrichment of $(->+)-4$ via recrystallization from ethanol. ${ }^{20}$ A sample of $(->+)-4(2.89 \mathrm{~g}$, ee $=83.5 \%)$ was recrystallized from dry ethanol $(5.8 \mathrm{ml})$. The solid racemic was filtered off $\left(0.14 \mathrm{~g},[\alpha]_{D}^{25}=-10.1(\mathrm{c}: 0.99, \mathrm{EtOH})\right.$, ee $\left.=11.8 \%\right)$ and the filtrate was concentrated in vacuo to give $\left(R_{a}\right)-(-)-4\left(2.20 \mathrm{~g}, 76 \%,[\alpha]_{D}^{25}=-84.4(\mathrm{c}: 0.92, \mathrm{EtOH}), e e=98.7 \%\right.$.

Metalation and derivatization of 4. General procedure: Diisopropylamine (3.15 equiv.) and 1-[2-(carboxymethyl)-6-ethylphenyl]-1H-pyrrole-2-carboxylic acid (4, 1.0 equiv.) were added at $-75{ }^{\circ} \mathrm{C}$ to a solution of potassium tert-butoxide (3.0 equiv.) in dry tetrahydrofuran $(20 \mathrm{ml})$. After stirring for 30 minutes at $-75{ }^{\circ} \mathrm{C}$ a hexane solution of butyllithium $(1.59 \mathrm{~mol} / \mathrm{l}, 3.0$ equiv. $)$ was added dropwise. The orange coloured mixture was stirred for further 4 hours at $-75{ }^{\circ} \mathrm{C}$ before being reacted with the electrophile (1 equiv.). After warming up to room temperature distilled water $(15 \mathrm{ml})$ and diethyl ether $(15 \mathrm{ml})$ were added, the phases were separated and the aqueous layer was washed with diethyl ether $(2 \times 15 \mathrm{ml})$. The aqueous layer was acidified with a $15 \%$ aqueous citric acid solution to precipitate the product (7) as oil or as crystals.

1-[2-(1-Carboxyethyl)-6-ethylphenyl]-1H-pyrrole-2-carboxylic acid (7a). Rac-7a and (+)-7a were prepared according to the general procedure as follows. Diisopropylamine $(11.7 \mathrm{mmol}$, $1.20 \mathrm{~g}, 1.65 \mathrm{ml}$ ) and 1-[2-(carboxymethyl)-6-ethylphenyl]-1H-pyrrole-2-carboxylic acid (rac-4, $3.7 \mathrm{mmol}, 1.00 \mathrm{~g})$ were added at $-75{ }^{\circ} \mathrm{C}$ to a solution of potassium tert-butoxide $(11,0 \mathrm{mmol}$, $1,24 \mathrm{~g})$ in dry tetrahydrofuran $(20 \mathrm{ml})$. After stirring for 30 minutes at $-75^{\circ} \mathrm{C}$ a hexane solution of butyllithium $(1.59 \mathrm{~mol} / \mathrm{l}, 11.3 \mathrm{mmol}, 7.1 \mathrm{ml})$ was added dropwise. The orange coloured mixture was stirred for further 4 hours at $-75{ }^{\circ} \mathrm{C}$ before iodomethane was added $(11.7 \mathrm{mmol}$, $1.66 \mathrm{~g}, 0.73 \mathrm{ml})$. After the working-up procedure the colourless crystals precipitated were filtered off, washed with ice-cold distilled water and dried to give $0.84 \mathrm{~g}$ of $7 \mathbf{a}$, yield $84 \%$. The crude product was purified by recrystallization or by selective precipitation.

a) Purification of 7a by recrystallization: the crude product was dissolved in hot ethyl acetate and precipitated with a fourfold amount of hexane. The white crystals were filtered, washed with cold hexane and dried.

b) Purification by selective precipitation: The crude product was dissolved in an equivalent amount of $1 \mathrm{M}$ aqueous sodium hydroxide solution before being precipitated and filtered off in several fractions by addition of $15 \%$ aqueous citric acid in small portions. NMR data of rac-7a are identical with the $\left(R_{a}, S\right)-(+)-7 \mathbf{a}$ enantiomer.

$\left(R_{a}, S\right)$-(+)-1-[2-(1-Carboxyethyl)-6-ethylphenyl]-1H-pyrrole-2-carboxylic acid $\left(\left(R_{a}, S\right)-(+)\right.$ 7a). Compound $\left(R_{a}, S\right)-(+)-7 \mathbf{a}$ was prepared according to the general procedure by using $\left(R_{a}\right)-(-)-$ 1-[2-(carboxymethyl)-6-ethylphenyl]-1 $H$-pyrrole-2-carboxylic acid $\left(3.7 \mathrm{mmol}, 1 \mathrm{~g},[\alpha]_{D}^{25}=-84.4\right.$ 
(c: $0.92, \mathrm{EtOH})$, ee $\left.=98.7 \%,\left(R_{a}\right)-(-)-4\right)$ as starting material. The product $(+)-7 \mathbf{a}$ was obtained as colourless crystals, yield $84 \%, \mathrm{mp} 164-166{ }^{\circ} \mathrm{C},[\alpha]_{D}^{25}=+53.1$ (c: 0.966 , EtOH). ${ }^{1} \mathrm{H}-\mathrm{NMR}(500$ MHz, DMSO- $\left.d_{6}\right): \delta_{\mathrm{H}} 1.01\left(3 \mathrm{H}, \mathrm{t}, J\right.$ 8.0, $\left.\mathrm{C}_{3}-\mathrm{CH}_{2}\right), 1.21\left(3 \mathrm{H}, \mathrm{d}, J 7.5, \mathrm{CH}_{3}\right), 2.17\left(2 \mathrm{H}, \mathrm{m}, \mathrm{CH}_{3}-\right.$ $\left.\mathrm{C}_{2}\right), 2.87\left(1 \mathrm{H}, \mathrm{q}, J 7.5-\mathrm{C} \underline{\mathrm{H}}-\mathrm{CH}_{3}\right), 6.32\left(1 \mathrm{H}, \mathrm{t}\right.$ like $\mathrm{m}, J$ 4.0, $\left.\mathrm{H}_{\beta}\right), 6.97\left(1 \mathrm{H}, \mathrm{t}\right.$ like $\mathrm{m}, J$ 2.5, $\left.\mathrm{H}_{\beta}\right)$, $6.98\left(1 \mathrm{H}, \mathrm{m}, \mathrm{H}_{\alpha^{\prime}}\right), 7.24(1 \mathrm{H}, \mathrm{d}, J$ 7.5, Ph), $7.29(1 \mathrm{H}, \mathrm{d}, J$ 7.5, Ph), $7.34(1 \mathrm{H}, \mathrm{t}, J 7.5, \mathrm{Ph}), 11.96$ $\left(2 \mathrm{H}\right.$, br s, OH); ${ }^{13} \mathrm{C}-\mathrm{NMR}\left(75 \mathrm{MHz}, \mathrm{DMSO}-d_{6}\right): \delta_{\mathrm{C}} 174.7,160.5,141.2,138.7,137.8,129.4$, 128.3 (2C), 126.6, 124.7, 117.1, 109.0, 38.7, 23.6, 19.9, 14.6; HRMS (EI): $\mathrm{m} / \mathrm{z} \mathrm{C}_{16} \mathrm{H}_{17} \mathrm{NO}_{4}$ $[\mathrm{M}+\mathrm{H}]^{+}$calc. 288.1236; found 288.1237.

1-[2-(1-Carboxy-3-methylbutyl)-6-ethylphenyl]-1H-pyrrole-2-carboxylic acid (7b). Rac-7b was prepared according to the general procedure by using isobutyl bromide $(8.78 \mathrm{mmol}, 1.2 \mathrm{~g}$, $0.96 \mathrm{ml}, 1.2$ equiv.) as electrophilic reagent. The crude product $(1.90 \mathrm{~g}, 79 \%)$ was suspended in ethyl acetate $(6 \mathrm{ml})$ and filtered off to give $1.20 \mathrm{~g}$ of $\mathbf{7 b}$ as white crystals, yield 50\%, mp 198-200 ${ }^{\circ} \mathrm{C} .{ }^{1} \mathrm{H}-\mathrm{NMR}\left(500 \mathrm{MHz}, \mathrm{CDCl}_{3}\right): \delta_{\mathrm{H}} 0.70\left(3 \mathrm{H}, \mathrm{d}, J 6.5, \mathrm{C}_{3}-\mathrm{CH}\right), 0.74\left(3 \mathrm{H}, \mathrm{d}, J\right.$ 6.5, $\left.\mathrm{C}_{3}-\mathrm{CH}\right)$, $1.06\left(3 \mathrm{H}, \mathrm{t}, J\right.$ 7.5, $\left.\underline{\mathrm{C}}_{3}-\mathrm{CH}_{2}\right), 1.37\left(1 \mathrm{H}, \mathrm{sep}, J\right.$ 6.5, $\left.\left(\mathrm{CH}_{3}\right)_{2} \mathrm{C} \underline{\mathrm{H}}\right), 1.52(1 \mathrm{H}, \mathrm{m},-\mathrm{C} \underline{\mathrm{HH}}), 1.88(1 \mathrm{H}$, quin, J 7.0, - $\mathrm{CH} \underline{\mathrm{H}}), 2.24$ (2H, sep, J 7.5, $\left.\mathrm{CH}_{3}-\underline{\mathrm{C}}_{2}\right), 2.97\left(1 \mathrm{H}, \mathrm{t}, J\right.$ 7.5, $\left.\mathrm{Ph}-\mathrm{C} \underline{\mathrm{H}}(\mathrm{COOH}) \mathrm{CH}_{2}\right), 6.37$ $\left(1 \mathrm{H}\right.$, dd like $\mathrm{m}, J$ 2.5, 4.0, $\left.\mathrm{H}_{\beta}{ }^{\prime}\right), 6.70\left(1 \mathrm{H}, \mathrm{m}, \mathrm{H}_{\beta}\right), 7.21(1 \mathrm{H}, \mathrm{d}, J 7.5, \mathrm{Ph}), 7.25\left(1 \mathrm{H}, \mathrm{m}, \mathrm{H}_{\alpha^{\prime}}\right), 7.37$ $(1 \mathrm{H}, \mathrm{t}, J 7.5, \mathrm{Ph}), 7.49\left(1 \mathrm{H}, \mathrm{d}\right.$ like m, $J$ 7.0, Ph), $12.26(2 \mathrm{H}, \mathrm{br} \mathrm{s}, \mathrm{OH}) ;{ }^{13} \mathrm{C}-\mathrm{NMR}(75 \mathrm{MHz}$, $\left.\mathrm{CDCl}_{3}\right): \delta_{\mathrm{C}} 181.3,165.9,141.2,138.2,136.8,130.3,129.0,127.7,126.2,124.4,120.1,110.3$, 43.6, 43.3, 26.3, 24.3, 22.7, 22.4, 15.1; HRMS (EI): m/z $\mathrm{C}_{19} \mathrm{H}_{23} \mathrm{NO}_{4}[\mathrm{M}+\mathrm{H}]^{+}$calc. 330.1705; found 330.1712 .

1-[2-(1-Carboxy-2-phenylethyl)-6-ethylphenyl]-1H-pyrrole-2-carboxylic acid (7c). Rac-7c was prepared according to the general procedure by using benzyl bromide $(7.32 \mathrm{mmol}, 1.25 \mathrm{~g}$, $0.87 \mathrm{ml}, 1.0$ equiv.) as reagent. The crude product ( $2.05 \mathrm{~g}, 77 \%)$ was suspended in ethyl acetate

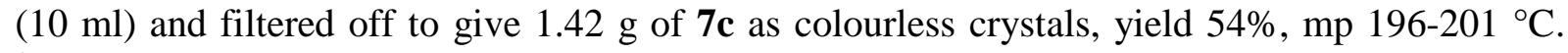
${ }^{1} \mathrm{H}-\mathrm{NMR}\left(500 \mathrm{MHz}, \mathrm{CDCl}_{3}\right): \delta_{\mathrm{H}} 0.99\left(3 \mathrm{H}, \mathrm{t}, J\right.$ 7.5, $\left.\mathrm{C}_{3}-\mathrm{CH}_{2}\right), 2.09\left(2 \mathrm{H}\right.$, sep, J 7.5, $\left.\mathrm{CH}_{3}-\mathrm{C}_{2}\right)$, 2.96 (1H, dd, $J$ 9.0, 12.5, -CㅌH-Ph), 3.05 (1H, dd, J 6.0, 9.0, - $\underline{\mathrm{H}}-\mathrm{COOH}), 3.15$ (1H, dd, $J$ 6.0, 12.5, -CHㅍ-Ph), $5.74\left(1 \mathrm{H}, \mathrm{t}\right.$ like $\mathrm{m}, J$ 2.0, $\left.\mathrm{H}_{\beta}\right), 6.17\left(1 \mathrm{H}\right.$, dd like $\left.\mathrm{m}, J 2.5,4.0, \mathrm{H}_{\beta}\right), 6.80(2 \mathrm{H}$, dd like $\mathrm{m}, J$ 2.0, 7.0, Ph), $7.12\left(3 \mathrm{H}, \mathrm{m}, \mathrm{Ph}+\mathrm{H}_{\alpha^{\prime}}\right), 7.18(2 \mathrm{H}, \mathrm{m}, \mathrm{Ph}), 7.40(1 \mathrm{H}, \mathrm{t}, J 7.5, \mathrm{Ph}), 7.68(1 \mathrm{H}$, $\mathrm{d}, J$ 7.5, Ph), $12.10\left(2 \mathrm{H}\right.$, br s, OH); ${ }^{13} \mathrm{C}-\mathrm{NMR}\left(75 \mathrm{MHz}, \mathrm{CDCl}_{3}\right): \delta_{\mathrm{C}} 180.0,165.6,141.2,138.3$, 138.2, 135.4, 130.5 (2C), 129.2, 128.8 (2C), 128.3, 127.7, 126.6, 125.9, 123.5, 119.9, 109.7, 47.4, 40.3, 24.0, 14.9; HRMS (EI): $\mathrm{m} / \mathrm{z} \mathrm{C}_{22} \mathrm{H}_{21} \mathrm{NO}_{4}[\mathrm{M}+\mathrm{H}]^{+}$calc. 364.1549; found 364.1537.

1-[2-(1-Carboxy-2-hydroxy-2-phenylethyl)-6-ethylphenyl]-1H-pyrrole-2-carboxylic acid (7d). Rac-7d was prepared according to the general procedure by using benzaldehyde (7.32 mmol, $0.78 \mathrm{~g}, 0.75 \mathrm{ml}, 1$ equiv.) as reagent. The crude product $(2.13 \mathrm{~g}, 80 \%)$ was suspended in hot ethyl acetate $(13 \mathrm{ml})$ and filtered off to give $1.98 \mathrm{~g}$ of $\mathbf{7 d}$ as colourless crystals, yield $74 \%$, mp 218-221 ${ }^{\circ} \mathrm{C} .{ }^{1} \mathrm{H}-\mathrm{NMR}\left(300 \mathrm{MHz}, \mathrm{DMSO}-d_{6}\right): \delta_{\mathrm{H}} 0.84\left(3 \mathrm{H}, \mathrm{t}, J 7.5, \mathrm{C}_{3}-\mathrm{CH}_{2}\right), 1.91(2 \mathrm{H}, \mathrm{q}, J$ 7.5, $\left.\mathrm{CH}_{3}-\underline{\mathrm{C}}_{2}\right), 2.89$ (1H, d, J 10.2, - $\left.\mathrm{C} \underline{\mathrm{H}}(\mathrm{COOH}) \mathrm{Ph}\right), 4.05$ (1H, dd like m, J 3.0, 10.2, - $\mathrm{C} \underline{\mathrm{H}}(\mathrm{OH})-$ 
$\mathrm{Ph}), 4.99$ (1H, br s, OH), $5.64\left(1 \mathrm{H}, \mathrm{d}\right.$ like $\left.\mathrm{m}, J 3.9, \mathrm{H}_{\beta}\right), 6.07\left(1 \mathrm{H}, \mathrm{t}\right.$ like $\left.\mathrm{m}, J 3.3, \mathrm{H}_{\beta}\right), 6.90(3 \mathrm{H}$, $\left.\mathrm{m}, \mathrm{Ph}+\mathrm{H}_{\alpha}\right), 7.17(4 \mathrm{H}, \mathrm{m}, \mathrm{Ph}), 7.38(1 \mathrm{H}, \mathrm{t}, J$ 7.5, Ph), $7.74(1 \mathrm{H}, \mathrm{d}, J$ 7.5, Ph), $11.94(2 \mathrm{H}$, br s, $\mathrm{OH}) ;{ }^{13} \mathrm{C}-\mathrm{NMR}\left(75 \mathrm{MHz}, \mathrm{DMSO}-d_{6}\right): \delta_{\mathrm{C}} 173.0,160.4,143.0,140.7,138.6,133.6,128.5,127.8$, 127.4 (2C), 127.1 (2C), 126.9 (2C), 126.5, 125.0, 116.9, 108.2, 75.6, 54.0, 22.4, 14.6; HRMS (EI): $\mathrm{m} / \mathrm{z} \mathrm{C}_{22} \mathrm{H}_{21} \mathrm{NO}_{5}[\mathrm{M}+\mathrm{H}]^{+}$calc. 380.1498; found 380.1494 .

$\left(R_{a}\right)$-(-)-1-[2-(Ethoxycarbonylmethyl)-6-ethylphenyl]-1H-pyrrole-2-carboxylic acid ( $\left(\boldsymbol{R}_{a}\right)$-(-)9b). Thionyl chloride $(22.8 \mathrm{mmol}, 2.71 \mathrm{~g}, 1.66 \mathrm{ml})$ was added dropwise at $0{ }^{\circ} \mathrm{C}$ to a solution of $(-$ )-1-[2-(carboxymethyl)-6-ethylphenyl]-1H-pyrrole-2-carboxylic acid $\left(\left(R_{a}\right)-(-)-4,15.2 \mathrm{mmol}\right.$, $4.15 \mathrm{~g},[\alpha]_{D}^{25}=-80.0$ (c: 1.0 , ethanol), ee $\left.=93.6 \%\right)$ in abs. ethanol $(100 \mathrm{ml})$. The reaction mixture was stirred at room temperature for 22 hours (TLC: hexane/ethyl acetate 1:1). The solvent and the excess of thionyl chloride were evaporated in vacuo. To remove traces of thionyl chloride, the residue was dissolved in ethanol $(2 \times 10 \mathrm{ml})$ and again evaporated. The crude product $(4.52$ $\mathrm{g}, 99 \%,[\alpha]_{D}^{25}=-63.6$ (c: 1.12 , ethanol)) was crystallized from ethyl acetate to yield $4.14 \mathrm{~g}$ of $\left(R_{a}\right)-(-)-9 b$ as colourless crystals, yield $90.4 \%, \mathrm{mp} 90-92{ }^{\circ} \mathrm{C},[\alpha]_{D}^{25}=-73.8$ (c: 1.0 , ethanol). ${ }^{1} \mathrm{H}-\mathrm{NMR}\left(300 \mathrm{MHz}, \mathrm{CDCl}_{3}\right.$ ): $\delta_{\mathrm{H}} 1.04\left(3 \mathrm{H}, \mathrm{t}, J\right.$ 7.5, $\left.\mathrm{CH}_{3}-\mathrm{CH}_{2}\right), 1.14$ (3H, t, J 6.9, $\left.\mathrm{CH}_{3}-\mathrm{CH}_{2}-\mathrm{O}\right)$, $2.18\left(2 \mathrm{H}, \mathrm{m},-\mathrm{C}_{2}-\mathrm{CH}_{3}\right), 3.16(1 \mathrm{H}, \mathrm{d}, J 15.9,-\mathrm{C} \underline{\mathrm{H}}), 3.26(1 \mathrm{H}, \mathrm{d}, J 15.9,-\mathrm{CH} \underline{\mathrm{H}}), 4.01$ (2H, q, $J$ 6.9, - $\left.\mathrm{O}-\mathrm{C}_{2}-\mathrm{CH}_{3}\right), 6.30\left(1 \mathrm{H}\right.$, dd like m, $J$ 2.4, 3.3, $\mathrm{H}_{\beta}$ ) $, 6.77\left(1 \mathrm{H}\right.$, t like m, $\left.J 1.8, \mathrm{H}_{\beta}\right), 7.19(3 \mathrm{H}$, $\left.\mathrm{m}, \mathrm{Ph}+\mathrm{H}_{\alpha^{\prime}}\right), 7.32\left(1 \mathrm{H}, \mathrm{t}, J\right.$ 7.5, Ph), $11.80(1 \mathrm{H}$, br s, OH $) ;{ }^{13} \mathrm{C}-\mathrm{NMR}\left(75 \mathrm{MHz}, \mathrm{CDCl}_{3}\right): \delta_{\mathrm{C}}$ 171.4, 165.3, 141.9, 138.4, 132.4, 131.1, 128.8, 128.0, 127.7, 123.1, 120.1, 109.9, 60.9, 37.1, $23.9,14.8,14.2$.

$\left(R_{a}, S\right)-(+)-1-[2-(1-E t h o x y c a r b o n y l e t h y l)-6-e t h y l p h e n y l]-1 H$-pyrrole-2-carboxylic $\quad$ acid $\left(\left(\boldsymbol{R}_{\boldsymbol{a}}, S\right)-(+)-9 \mathrm{a}\right)$ by selective esterification. Thionyl chloride $(1.05 \mathrm{mmol}, 0.12 \mathrm{~g}, 0.076 \mathrm{ml})$ was added dropwise at $0{ }^{\circ} \mathrm{C}$ during 15 minutes to a solution of $(S)-(+)-1-[2-(1$-carboxyethyl)-6ethylphenyl]-1H-pyrrole-2-carboxylic acid $\left(\left(R_{a}, S\right)-(+)-7 \mathbf{a}, 0.7 \mathrm{mmol}, 0.2 \mathrm{~g},[\alpha]_{D}^{25}=+53.1\right.$ (c: 1.0 , ethanol), ee $=98.7 \%)$ in abs. ethanol $(8 \mathrm{ml})$. The mixture was stirred for 2 hours at $0{ }^{\circ} \mathrm{C}$ and for additional 3 hours at room temperature until the starting dicarboxylic acid consumed (TLC control, eluent: hexane/ethyl acetate $=1 / 1$ ). The solvent and the excess of thionyl chloride were evaporated in vacuo. To remove traces of thionyl chloride, the residue was dissolved in ethanol $(2 \times 10 \mathrm{ml})$ and again evaporated. The crude product was treated with active coal in ethyl acetate, filtered through Celite and evaporated in vacuo to give $0.18 \mathrm{~g}$ of $\left(R_{a}, S\right)-(+)-9 \mathrm{a}$ as colourless crystals, yield $82 \%, \mathrm{mp} 95-96{ }^{\circ} \mathrm{C},[\alpha]_{D}^{25}=+77.5$ (c: 1.0 , ethanol). ${ }^{1} \mathrm{H}-\mathrm{NMR}\left(300 \mathrm{MHz}, \mathrm{CDCl}_{3}\right)$ : $\delta_{\mathrm{H}} 1.05\left(3 \mathrm{H}, \mathrm{t}, J\right.$ 7.2, $\left.\mathrm{CH}_{3}-\mathrm{CH}_{2}\right), 1.06\left(3 \mathrm{H}, \mathrm{t}, J\right.$ 7.5, $\left.\underline{\mathrm{CH}}_{3}-\mathrm{CH}_{2}-\mathrm{O}-\right), 1.30$ (3H, d, J 7.2, $\left.\mathrm{CH}_{3}-\mathrm{CH}-\right)$, $2.22\left(2 \mathrm{H}\right.$, sep, J 7.2, $\left.\mathrm{CH}_{3}-\underline{\mathrm{CH}}_{2}\right), 3.01\left(1 \mathrm{H}, \mathrm{q}, J\right.$ 7.2 $\left.-\underline{\mathrm{CH}}-\mathrm{CH}_{3}\right), 3.95\left(2 \mathrm{H}, \mathrm{dq}, J 1.8,7.2 \mathrm{CH}_{3}-\mathrm{CH}_{2}-\right.$ O), $6.35\left(1 \mathrm{H}\right.$, dd like m, $J$ 2.7, 3.9, $\left.\mathrm{H}_{\beta}{ }^{\prime}\right), 6.73\left(1 \mathrm{H}, \mathrm{t}\right.$ like $\left.\mathrm{m}, J 2.1, \mathrm{H}_{\beta}\right), 7.30\left(4 \mathrm{H}, \mathrm{m}, \mathrm{Ph}+\mathrm{H}_{\alpha^{\prime}}\right)$, $11.82(1 \mathrm{H}$, br s, $\mathrm{OH}) ;{ }^{13} \mathrm{C}-\mathrm{NMR}\left(75 \mathrm{MHz}, \mathrm{CDCl}_{3}\right)$ : $\delta_{\mathrm{C}} 174.3,164.3,142.0,138.8,137.6,130.2$, 129.2, 127.3, 125.1, 124.3, 119.8, 110.1, 66.1, 39.8, 24.1, 15.5, 14.6, 14.0. 
$\left(R_{a}, S\right)-(+)-1-[2-(1-E t h o x y c a r b o n y l e t h y l)-6-e t h y l p h e n y l]-1 H$-pyrrole-2-carboxylic $\quad$ acid $\left(\left(R_{a}, S\right)-(+)-9 a\right)$ by selective hydrolysis of $\left(R_{a}, S\right)-(+)-11$ a diester. a) Preparation of ethyl $\left(R_{a}, S\right)$ (+)-1-[2-(1-ethoxycarbonylethyl)-6-ethylphenyl]-1H-pyrrole-2-carboxylate $\quad\left(\left(R_{a}, S\right)-(+)-11 \mathrm{a}\right)$ : Thionyl chloride $(7.35 \mathrm{mmol}, 0.87 \mathrm{~g}, 0.53 \mathrm{ml})$ was added dropwise to a solution of (+)-1-[2-(1carboxyethyl)-6-ethylphenyl]-1H-pyrrole-2-carboxylic acid $\left(\left(R_{a}, S\right)-(+)-7 \mathbf{a}, 1.05 \mathrm{mmol}, 0.3 \mathrm{~g}\right.$, $[\alpha]_{D}^{25}=+53.1$ (c: 1.0 , ethanol)) in abs. ethanol $(12 \mathrm{ml})$ at $0{ }^{\circ} \mathrm{C}$. The dark blue mixture was stirred for 2 days at room temperature (TLC control, eluent: ethyl acetate/methanol $=6 / 1$ ). The solvent and the excess of thionyl chloride were evaporated in vacuo. The residue (green oil) was treated with active coal in ethyl acetate, filtered through Celite and evaporated in vacuo to give $0.35 \mathrm{~g}$ $(97 \%)$ of $\left(R_{a}, S\right)-(+)-11 a$ diester. The crude product (light yellow amorphous crystals) was used in the next step without further purification.

${ }^{1} \mathrm{H}-\mathrm{NMR}\left(300 \mathrm{MHz}, \mathrm{CDCl}_{3}\right): \delta_{\mathrm{H}} 1.06\left(6 \mathrm{H}, \mathrm{t}, J\right.$ 8.1, 2x $\left.\mathrm{CH}_{3}-\mathrm{CH}_{2}\right), 1.24\left(3 \mathrm{H}, \mathrm{t}, J\right.$ 7.2, $\left.\mathrm{CH}_{3}-\mathrm{CH}_{2}\right)$, $1.31\left(3 \mathrm{H}, \mathrm{d}, J\right.$ 7.2, - $\left.\mathrm{CH}-\underline{\mathrm{C}}_{3}\right), 2.23\left(2 \mathrm{H}, \mathrm{sep}, J 7.2, \mathrm{CH}_{3}-\underline{\mathrm{CH}}_{2}\right), 3.02\left(1 \mathrm{H}, \mathrm{q}, J 7.2-\underline{\mathrm{CH}}-\mathrm{CH}_{3}\right), 3.72$ $\left(2 \mathrm{H}, \mathrm{q}, J\right.$ 7.2, $\left.\mathrm{CH}_{3}-\underline{\mathrm{C}}_{2}-\mathrm{O}\right), 3.95\left(2 \mathrm{H}, \mathrm{dq}, J\right.$ 2.7, $\left.7.2 \mathrm{CH}_{3}-\underline{\mathrm{C}}_{2}-\mathrm{O}\right), 6.36$ (1H, t like m, $J 3.3, \mathrm{H}_{\beta}$ ), $6.73\left(1 \mathrm{H}, \mathrm{m}, \mathrm{H}_{\beta}\right), 7.30\left(4 \mathrm{H}, \mathrm{m}, \mathrm{Ph}+\mathrm{H}_{\alpha^{\prime}}\right)$.

b) Preparation of $\left(R_{a}, S\right)-(+)-9$ a from $\left(R_{a}, S\right)-(+)-11$ a by selective hydrolysis: Ethyl $\left(R_{a}, S\right)-(+)-1-$ [2-(ethoxycarbonylmethyl)-6-ethylphenyl]-1H-pyrrole-2-carboxylate $\quad\left(\left(R_{a}, S\right)-(+)-11 \mathrm{a}, \quad 0.96\right.$ mmol, $0.34 \mathrm{~g})$ was dissolved in the previously prepared solution of sodium hydroxide $(0.96$ mmol, $0.0385 \mathrm{~g}, 1$ equiv. $)$ in ethanol $(10 \mathrm{ml})$ and water $(0.1 \mathrm{ml})$. The solution was stirred at room temperature for 2 days (TLC control, eluent: hexane/ethyl acetate $=1 / 1$ ). The mixture was evaporated in vacuo, the residue was dissolved in water and acidified with $5 \%$ aqueous hydrochloric acid solution $(0.96 \mathrm{mmol}, 7 \mathrm{ml})$. The aqueous mixture was extracted with ethyl acetate $(2 \times 15 \mathrm{ml})$. The collected organic solutions were washed with distilled water $(15 \mathrm{ml})$ and brine $(15 \mathrm{ml})$. The organic phase was dried over sodium sulphate and concentrated in vacuo to give $0.18 \mathrm{~g}(+)-9 \mathrm{a}$ as colourless crystals, yield 60\%, mp 95-96 ${ }^{\circ} \mathrm{C}[\alpha]_{D}^{25}=+78.2(\mathrm{c}: 1.016$, ethanol).

\section{General method for the synthesis of acid amides $12 \mathrm{a}$ and $\mathbf{1 2 b}$}

Thionyl chloride ( 2 equiv.) was added dropwise at $0{ }^{\circ} \mathrm{C}$ to a solution of the optical active monoester (7a or $7 \mathbf{b}, 1$ equiv.) in dry toluene $(15 \mathrm{ml})$, in the presence of $2-3$ drop of dry dimethylformamide. The mixture was stirred at $70{ }^{\circ} \mathrm{C}$ for 2 hours. The solvent and the excess of thionyl chloride were evaporated in vacuo. To remove traces of thionyl chloride, the residue was dissolved in toluene and again evaporated. The residue containing the acid chloride was dissolved in dry toluene $(10 \mathrm{ml})$, and then a solution of diethylamine ( 3 equiv.) in dry toluene (5 $\mathrm{ml}$ ) was added at $0{ }^{\circ} \mathrm{C}$. The mixture was stirred at room temperature (TLC control, eluent: hexane/ethyl acetate $=1 / 1$ ) for 30 minutes. Toluene was evaporated in vacuo and the residue was dissolved in ethyl acetate $(15 \mathrm{ml})$. The solution was acidified with $5 \%$ aqueous hydrochloric acid solution $(15 \mathrm{ml})$. The phases were separated; the organic phase was washed with saturated $\mathrm{NaHCO}_{3}$-solution, water and brine. The organic phase was dried over sodium sulphate and concentrated in vacuo to give the $\mathbf{1 2 \mathbf { a }}$ or $\mathbf{1 2 b}$ amides. 
$\left(R_{a}, S\right)-(+)-N, N$-Diethyl 1-[2-(1-ethoxycarbonylethyl)-6-ethylphenyl]-1H-pyrrole-2-carboxamide $\left(\left(R_{a}, S\right)-(+)-12 a\right)$. Prepared from $(+)-1-[2-(1-$ ethoxycarbonylethyl)-6-ethylphenyl]-1Hpyrrole-2-carboxylic acid $\left(\left(R_{a}, S\right)-(+)-9 \mathrm{a}\right)\left(1.68 \mathrm{mmol}, 0.53 \mathrm{~g},[\alpha]_{D}^{25}=+35.1\right.$ (c: 0.9 , ethanol), ee $=65.3 \%)$. The product $\left(R_{a}, S\right)-(+)-12 \mathrm{a}(0.55 \mathrm{~g})$ was isolated as a yellow oil, yield $89 \%$, $[\alpha]_{D}^{25}=-78.8$ (c: 0.7, ethanol). ${ }^{1} \mathrm{H}-\mathrm{NMR}\left(500 \mathrm{MHz}, \mathrm{CDCl}_{3}\right): \delta_{\mathrm{H}} 1.16\left(12 \mathrm{H}, \mathrm{m}, 4 \times \mathrm{x}_{3}-\mathrm{CH}_{2}\right)$, $1.30\left(3 \mathrm{H}, \mathrm{d}, J 7.0,-\mathrm{CH}-\underline{\mathrm{H}}_{3}\right), 2.35$ (1H, quint, $\left.J 7.5,-\mathrm{C} \underline{\mathrm{HH}}\right), 2.47$ (1H, quint, $J$ 7.5, -CH$\left.\underline{\mathrm{H}}\right), 3.15$ $\left(1 \mathrm{H}, \mathrm{q}, J\right.$ 7.0, $\left.-\mathrm{C} \underline{\mathrm{H}}-\mathrm{CH}_{3}\right), 3.39\left(2 \mathrm{H}, \mathrm{m}, \mathrm{CH}_{3}-\underline{\mathrm{C}}_{2}-\mathrm{N}\right), 3.59\left(2 \mathrm{H}\right.$, br s like m, $\left.\mathrm{CH}_{3}-\underline{\mathrm{C}}_{2}-\mathrm{N}\right), 4.03$ $\left(2 \mathrm{H}, \mathrm{m}, \mathrm{CH}_{3}-\underline{\mathrm{C}}_{2}-\mathrm{O}\right), 6.28\left(1 \mathrm{H}, \mathrm{t}\right.$ like $\left.\mathrm{m}, J 3.5, \mathrm{H}_{\beta}\right), 6.56\left(1 \mathrm{H}, \mathrm{m}, \mathrm{H}_{\beta}\right), 6.62\left(1 \mathrm{H}, \mathrm{m}, \mathrm{H}_{\alpha}{ }^{\prime}\right), 7.23$ $(2 \mathrm{H}, \mathrm{m}, \mathrm{Ph}), 7.31(1 \mathrm{H}, \mathrm{t}, J 7.5, \mathrm{Ph}) ;{ }^{13} \mathrm{C}-\mathrm{NMR}\left(125 \mathrm{MHz}, \mathrm{CDCl}_{3}\right): \delta_{\mathrm{C}} 174.2,162.1,143.0,138.6$, 137.6, 128.7, 127.8, 126.6, 126.3, 124.6, 111.3, 107.7, 60.6, 40.2, 37.5, 24.2, 23.8, 20.6, 14.9, 14.5, 14.2, 13.7. HRMS (EI): $\mathrm{m} / \mathrm{z} \mathrm{C}_{22} \mathrm{H}_{30} \mathrm{~N}_{2} \mathrm{O}_{3}[\mathrm{M}+\mathrm{H}]^{+}$calc. 371.2334; found 371.2321.

$\left(R_{a}, S\right)-(-)-N, N$-Diethyl 1-[2-(ethoxycarbonylmethyl)-6-ethylphenyl]-1H-pyrrole-2-carboxamide $\left(\left(\boldsymbol{R}_{\boldsymbol{a}}, S\right)-(-)-12 b\right)$. Prepared from (-)-1-[2-(ethoxycarbonylmethyl)-6-ethylphenyl]-1Hpyrrole-2-carboxylic acid $\left(\left(R_{a}, S\right)-(-)-9 b\right)\left(4.41 \mathrm{mmol}, 1.33 \mathrm{~g},[\alpha]_{D}^{25}=-71.6\right.$ (c: 1.0 , ethanol), ee $=97.0 \%)$. The crude product $\left(R_{a}, S\right)-(-)-\mathbf{1 2 b}(1.49 \mathrm{~g}, 95 \%$, yellow oil $)$ was purified by column chromatography (hexane/ethyl acetate $=1 / 1)$ to give $1.40 \mathrm{~g}$ of $\left(R_{a}, S\right)-(-)-\mathbf{1 2 b}$ as yellow oil, yield $89 \%,[\alpha]_{D}^{25}=-115.8$ (c: 1.0 , ethanol). ${ }^{1} \mathrm{H}-\mathrm{NMR}\left(500 \mathrm{MHz}, \mathrm{CDCl}_{3}\right): \delta_{\mathrm{H}} 1.07\left(3 \mathrm{H}, \mathrm{t}, J 7.5, \mathrm{C}_{3_{3}}-\right.$ $\left.\mathrm{CH}_{2}\right), 1.14\left(6 \mathrm{H}, \mathrm{m}\right.$ like br s, $\left.2 \mathrm{x}-\mathrm{C}_{3}-\mathrm{CH}_{2}-\mathrm{N}\right), 1.19\left(3 \mathrm{H}, \mathrm{t}, J\right.$ 7.5, $\left.\mathrm{C}_{3}-\mathrm{CH}_{2}-\mathrm{O}\right), 2.21$ (2H, q, $J$ 7.5, $\left.\mathrm{CH}_{3}-\underline{\mathrm{C}}_{2}\right), 3.43\left(4 \mathrm{H}\right.$, br s like m, $\left.\mathrm{CH}_{3}-\underline{\mathrm{C}}_{2}+\mathrm{CH}_{3}-\underline{\mathrm{C}}_{2}-\mathrm{N}\right), 3.56$ (2H, br s like m, $\mathrm{CH}_{3}-\underline{\mathrm{C}}_{2}-$ $\mathrm{N}), 4.06\left(2 \mathrm{H}, \mathrm{q}, J\right.$ 7.5, $\left.\mathrm{CH}_{3}-\underline{\mathrm{C}}_{2}-\mathrm{O}\right), 6.24\left(1 \mathrm{H}, \mathrm{t}\right.$ like $\mathrm{m}, J$ 2.5, $\left.\mathrm{H}_{\beta}\right), 6.51(1 \mathrm{H}$, dd like $\mathrm{m}, J 1.5$, 4.0, $\left.\mathrm{H}_{\beta}\right), 6.67\left(1 \mathrm{H}, \mathrm{t}\right.$ like $\left.\mathrm{m}, J 2.0, \mathrm{H}_{\alpha^{\prime}}\right), 7.19(2 \mathrm{H}$, dd like $\mathrm{m}, J 3.0,8.0, \mathrm{Ph}), 7.30(1 \mathrm{H}, \mathrm{t}, J$ 8.0, $\mathrm{Ph}) .{ }^{13} \mathrm{C}-\mathrm{NMR}\left(75 \mathrm{MHz}, \mathrm{CDCl}_{3}\right): \delta_{\mathrm{C}} 172.0,162.5,142.0,138.7,133.5,128.7,128.0,127.5$, $127.4,126.8,111.3,107.7,60.8,37.7$ (2C), 23.9, 15.1 (2C), 14.4 (3C). HRMS (EI): m/z $\mathrm{C}_{21} \mathrm{H}_{28} \mathrm{~N}_{2} \mathrm{O}_{3}[\mathrm{M}+\mathrm{H}]^{+}$calc. 357.2178; found 357.2164.

\section{Single crystal X-ray diffraction measurement of $\left(R_{a}, S\right)-(+)-7$ a}

Crystal data: $\mathrm{C}_{16} \mathrm{H}_{17} \mathrm{NO}_{4}$, Fwt.: 287.31, colourless, prism, size: 0.45 × 0.45 x $0.30 \mathrm{~mm}$, orthorhombic, space group $P 2_{1} 2_{1} 2_{1}, a=8.1717(6) \AA, b=8.9080(7) \AA, c=21.0551(18) \AA$, $\alpha=90.00^{\circ}, \beta=90.00^{\circ}, \gamma=90.00^{\circ}, V=1532.7(2) \AA^{3}, T=295(2) \mathrm{K}, Z=4, F(000)=608, D_{x}=$ $1.245 \mathrm{Mg} / \mathrm{m}^{3}, \mu=0.090 \mathrm{~mm}^{-1}$.

A crystal of $\left(R_{a}, S\right)-(+)-7 \mathbf{a}$ was mounted on a loop. Cell parameters were determined by leastsquares using $15344\left(3.00 \leq \theta \leq 25.67^{\circ}\right)$ reflections. Intensity data were collected on a(n) Rigaku

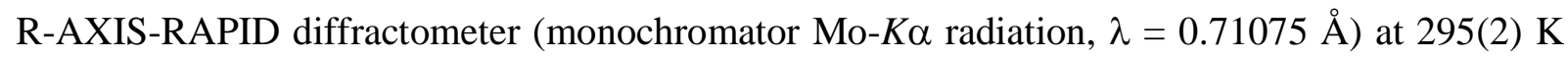
in the range $3.00 \leq \theta \leq 22.21^{24}$. A total of 21813 reflections were collected of which 1935 were unique $[R(\mathrm{int})=0.0423, R(\sigma)=0.0235]$; intensities of 1609 reflections were greater than $2 \sigma(I)$. Completeness to $\theta=0.997$. A numerical absorption correction ${ }^{25}$ was applied to the data (the minimum and maximum transmission factors were 0.962 and 0.983 ).

The structure was solved by direct methods ${ }^{26}$ (and subsequent difference syntheses). Anisotropic full-matrix least-squares refinement ${ }^{26}$ on $F^{2}$ for all non-hydrogen atoms yielded $R_{1}=0.0415$ and 
$w R^{2}=0.1017$ for $1332[I>2 \sigma(I)]$ and $R_{1}=0.0511$ and $w R^{2}=0.1058$ for all (1935) intensity data, (number of parameters $=192$, goodness-of-fit $=1.060$, the maximum and mean shift/esd is 0.000 and 0.000). The maximum and minimum residual electron density in the final difference map was 0.1 and -0.1 e. $\AA^{-3}$.

The weighting scheme applied was $w=1 /\left[\sigma^{2}\left(F_{o}{ }^{2}\right)+(0.0639 P)^{2}+0.0176 P\right]$ where $P=\left(F_{o}{ }^{2}+2 F_{c}{ }^{2}\right) / 3$. Hydrogen atomic positions were calculated from assumed geometries $\mathrm{H} 1 \mathrm{O}$ and $\mathrm{H} 4 \mathrm{O}$. Hydrogen atoms were included in structure factor calculations but they were not refined. The isotropic displacement parameters of the hydrogen atoms were approximated from the $U(\mathrm{eq})$ value of the atom they were bonded to. ORTEP style molecular structure diagram can be found in Figure 1, further data are given in the supplement.

Crystallographic data (including structure factors) for the structure in this paper have been deposited with the Cambridge Crystallographic Data Centre as supplementary publication nos. CCDC 1032325. The compound number in these files is: BBEB09. Copies of the data can be obtained, free of charge, on application to CCDC, 12 Union Road, Cambridge CB2 1EZ, UK, (fax: ţ44-(0)1223 336033 or e-mail: deposit@ccdc.cam.ac.uk).

\section{Acknowledgements}

The project was supported by the Hungarian Scientific Research Fund (OTKA K 104528) and it is connected to the New Széchenyi Development Plan (TÁMOP-4.2.1/B-09/1/KMR-2010-0002).

\section{References}

1. Eliel, E. L.; Wilen, S. H. Stereochemistry of Organic Compounds; Wiley: New York, 1994.

2. Leseurre, L.; Puentener, K.; Genet, J-P.; Scalone, M.; Michelet, V. Adv. Synth. Catal. 2011, $353,3269$.

http://dx.doi.org/10.1002/adsc.201100535

3. Clayden, J.; Fletcher, S. P.; Senior, J.; Worrall, C. P. Tetrahedron: Asymmetry 2010, 21, 1355.

http://dx.doi.org/10.1016/j.tetasy.2010.06.017

4. Kim, D. E.; Choi, C.; Kim, I. S.; Jeulin, S.; Ratovelomanana-Vidal, V.; Genet, J.-P.; Jeong, N. Adv. Synth. Catal. 2007, 349, 1999.

http://dx.doi.org/10.1002/adsc.200600623

5. Bulliard, M. Speciality Chemicals Magazine 2004, 24, 20.

6. Campolo, D.; Gastaldi, S.; Roussel, C.; Bertrand, M. P.; Nechab, M. Chem. Soc. Rev. 2013, 42,8434 .

http://dx.doi.org/10.1039/c3es60182j 
7. Clayden, J.; Westlund, N.; Wilson, F. X. Tetrahedron Lett. 1996, 37, 5577. http://dx.doi.org/10.1016/0040-4039(96)01129-X

8. Bowles, P.; Clayden, J.; Heliwell, M.; McCarthy, C.; Tomkinson, M.; Westlund, N. J. Chem. Soc. Perkin Trans 1 1997, 2607. http://dx.doi.org/10.1039/a701671i

9. Clayden, J.; Darbyshire, M.; Pink, J.; Westlund, N.; Wilson, F. X. Tetrahedron Lett. 1997, $38,8587$. http://dx.doi.org/10.1016/S0040-4039(97)10289-1

10. Hughes, A.; Price, D. A.; Shiskin, O.; Simpkins, N. Tetrahedron Lett. 1996, 37, 7607. http://dx.doi.org/10.1016/0040-4039(96)01673-5

11. Clayden, J.; Lund, A.; Youssef, L. H. Org. Lett. 2001, 3, 4133. http://dx.doi.org/10.1021/o10167457

12. Clayden, J.; Turner, H.; Helliwell, M.; Moir, E. J. Org. Chem. 2008, 73, 4415. http://dx.doi.org/10.1021/jo702706c

13. Fletcher, S. P.; Solà, J.; Holt, D.; Brown, R. A.; Clayden, J. Beilstein J. Org. Chem. 2011, 7, 1327. http://dx.doi.org/10.3762/bjoc.7.152

14. Wheatley, A. E. H.; Clayden, J.; Hillier, I. H.; Smith, A. C.; Vincent, A. M.; Taylor, L. J.; Haywood, J. Beilstein J. Org. Chem. 2012, 8, 50. http://dx.doi.org/10.3762/bjoc.8.5

15. Zhang, Y.; Wang, Y.; Dai, W. M. J. Org. Chem. 2006, 71, 2445. http://dx.doi.org/10.1021/jo0526486

16. Clayden, J. Chem. Soc. Rev. 2009, 38, 817.

17. Fogassy, K.; Harmat, V.; Böcskei, Zs.; Tárkányi, G.; Töke, L.; Faigl, F. Tetrahedron: Asymmetry 2000, 11, 4771. http://dx.doi.org/10.1016/S0957-4166(00)00449-3

18. Faigl, F.; Tárkányi, G.; Fogassy, K.; Tepfenhart, D.; Thurner, A. Tetrahedron 2008, 64, 1371.

http://dx.doi.org/10.1016/j.tet.2007.11.058

19. Faigl, F.; Vas-Feldhoffer, B.; Kudar, V.; Czugler, M.; Pál, K.; Kubinyi, M. Chirality 2009, 21,905 .

http://dx.doi.org/10.1002/chir.20686

20. Faigl, F.; Vas-Feldhoffer, B.; Kubinyi, M.; Pál, K.; Tárkányi, G.; Czugler, M. Tetrahedron: Asymmetry 2009, 20, 98.

http://dx.doi.org/10.1016/j.tetasy.2009.01.010

21. Faigl, F.; Mátravölgyi, B.; Holczbauer, T.; Czugler, M.; Madarász, J. Tetrahedron: Asymmetry 2011, 22, 1879.

http://dx.doi.org/10.1016/j.tetasy.2011.10.021 
22. Faigl, F.; Mátravölgyi, B.; Szöllősy, Á.; Czugler, M.; Tárkányi, G.; Vékey, K.; Kubinyi, M. Chirality 2012, 24, 532.

http://dx.doi.org/10.1002/chir.22049

23. PLATON: Spek, A. L. J. Appl. Cryst. 2003, 36, 7.

24. CrystalClear SM 1.4.0 (Rigaku/MSC Inc., 2008).

25. NUMABS: Higashi, T. 1998, rev. 2002. (Rigaku/MSC Inc.)

26. Sheldrick, G. M. Acta Cryst. 2008, A64, 112. http://dx.doi.org/10.1107/S0108767307043930 